\title{
Sistem Pendukung Keputusan Status Gizi Balita untuk Membantu Kinerja Puskesmas dengan Metode Fuzzy Tsukamoto
}

\author{
Riris Nur Sasmi a,1, Tedy Setiadi ${ }^{\mathrm{b}, 2}$ \\ a,b ProgramStudi Teknik Informatika Universitas Ahmad Dahlan \\ Jl. Ringroad Selatan, Kragilan, Tamanan, Kec. Banguntapan, Bantul,,Yogyakarta 55191 \\ ${ }^{1}$ ririsnursasmi2@gmail.com, ${ }^{2}$ tedy.setiadi@tif.uad.ac.id
}

\begin{abstract}
ABSTRAK
Status gizi balita merupakan hal yang penting untuk diperhatikan oleh orang tua, masyarakat, dan juga pemerintah karena menyangkut kualitas generasi penerus bangsa. Pada saat ini pengukuran status gizi pada Puskesmas dilakukan secara manual. Untuk menentuan klasifikasi status gizi pada balita oleh para ahli gizi dengan melihat acuan pada Kartu Menuju Sehat (KMS). Adanya beberapa kekurangan yang dimiliki manusia sehingga memungkinkan terjadinya kesalahan baik dalam pengukuran maupun perhitungan status gizi. Melihat persoalan ini makadiperlukanmedia informasi lain yang memudahkan untuk menentukan status gizi. Media yang dimanfaatkan adalah Sistem Pendukung Keputusan (SPK).
\end{abstract}

Subjek penelitian ini adalah membuat Sistem Pendukung Keputusan Status Gizi Balita dengan metode Fuzzy Tsukamoto. Tahap pengembangan aplikasi diawali dengan tahap analisis sistem meliputi analisis data, deskripsi kebutuhan sistem dan rekayasa pengetahuan yang disajikan dalam bentuk tabel basis pengetahuan, tabel keputusan, tabel aturan, diagram konteks, diagram alir data, entity relationship diagram dan tabel perancangan sistem meliputi spesifikasi proses, perancangan mapping table dan perancangan antarmuka. Tahap akhir adalah implementasi dan pengujian aplikasi. Aplikasi ini menggunakan bahasa pemrograman PHP dengan menggunakan database MySql.

Dari penlitian yang dilakukan menghasilkan perangkat lunak "Sistem Pendukung Keputusan Status Gizi Balita" yang dapat digunakan untuk menentukan status gizi balita dengan metode Fuzzy Tsukamoto. hasil dari keputusannya berupa status gizi lebik, status gizi baik, status gizi kurang atau status gizi buruk.

Kata Kunci : Fuzzy Tsukamoto,Sistem Pendukung Keputusan,Sta tus Gizi Balita

\section{Pendahuluan}

Masalah kesehatan dan gizi, diantaranya masalah kurang energi protein (KEP).Dalam penilaian status gizi, antropometri disajikan dalam bentuk indeks yang dikaitkan dengan variable lain, seperti: berat badan menurut umur $(\mathrm{BB} / \mathrm{U})$, panjang badan atau tinggi badan menurut umur $(\mathrm{PB} / \mathrm{U}$ atau $\mathrm{TB} / \mathrm{U})$, berat badan menurut tinggi badan $(\mathrm{BB} / \mathrm{TB})$ dan lain-lain. Masing-masing indeks antropometri tersebut memiliki baku rujukan atau nilai patokan untuk memperkirakan status gizi seseorang atau masyarakat. Baku rujukan tersebut dapat menggunakan nilai mean dan standar deviasi, persentil, persentase, maupun perhitungan z- score.Baku rujukan tersebut dapat menggunakan nilai mean dan standar deviasi, persentil, persentase, maupun perhitungan z-score. Namun, untuk mempermudahkan dalam penilaian status gizi terdapat grafik pertumbuhan standar yang dikeluarkan oleh Centers for Disease Control and Prevention (CDC) tahun 2000 dengan menggunakan kurva persentil dan World Health Organization (WHO) tahun 2005 dengan menggunakan kurva z-score[1]. 
Penghitungan status gizi balita pada umunya dilakukan di Puskesmas, Rumah sakit anak dan Posyandu. Untuk menentuan klasifikasi status gizi pada balita oleh para ahli gizi dengan melihat acuan pada Kartu Menuju Sehat (KMS). Kartu Menuju Sehat (KMS) adalah kartu yang memuat kurva pertumbuhan normal anak berdasarkan indeks antropometri berat badan menurut umur. Itu artinya status gizi hanya dapat dideteksi menurut umur dan berat badannya. Sedangkan untuk status gizi berdasar antropometri tinggi atau panjang badan menurut umur dan berat badan menurut timggi badan belum ada. Padahal data tersebut juga perlu untuk melihat status gizi balita pada masa lampau dan untuk menentukan proporsi badan balita tersebut[2].

Berdasarkan permasalahan tersebut maka perlu dikembangkan perangkat lunak dengan kemampuan sama atau mendekati seorang pakar untuk penentuan status gizi dan masa imunisasi balita. Berdasarkan hal tersebut, maka dalam membangun sistem pendukung keputusan untuk menentukan status gizi balita menggunakan logika fuzzy yang mampu menangani ketidakjelasan dan ketidakpastian dari berbagai variabel penghitungan status gizi balita yang digunakan. Logika fuzzy yang digunakan adalah sistem inferensi fuzzy Tsukamoto karena metode ini menggunakan aplikasi nilai monoton, Output hasil inferensi dari tiap-tiap aturan diberikan secara tegas (crisp) berdasarkan $\alpha$-predikat (fire strength). Maka Puskesmas membutuhkan bidang ini dengan mengambil judul "Sistem Pendukung Keputusan Untuk Membantu Kinerja Puskesmas Dengan Metode Fuzzy Tsukamoto.

\section{Landasan Teori}

\subsection{Kajian Pustaka Terdahulu}

Penelitian yang dilakukan dengan mengacu pada penelitian terdahulu yang dilakukan [3] dengan judul Sistem Pendukung Keputusan Penentuan Status Gizi Balita. Penelitian tersebut membahas tentang penilaian status gizi pada balita yang dilakukan dengan pemeriksaan langsung yaitu antrophometri dengan parameter umur, tinggi badan dan berat badan dan klinis dengan pemeriksaan fisik. Dan perhitungan dilakukan dengan teori Bayes. Aplikasi ini sudah mempunyai form - form yang cukup baik, tetapi aplikasi ini belum belum di lengkapi dengan laporan gizi balita untuk tiap bulannya.

Penelitian yang lain yang menjadi acuan dalam tugas akhir adalah penelitian [4] dengan judul Sistem Pendukung Keputusan Berbasis Pocket PC Sebagai Penentu Status Gizi Menggunakan Metode K-Nearest Neighbor, penelitian tersebut membahas tentang status gizi dan pengukuran antropometri menggunakan berat badan (BB), tinggi badan (TB), lingkar lengan atas (LLA), lapisan lemak bawah kulit (LLBK), lingkar perut dan sebagainya kemudian keputusannya menggunakan metode K-Nearest Neighbor (KKN) dengan objek penelitian mahasiswa yang di atas 17 tahun berdasarkan parameter kondisi fisik dari orang tersebut. KKN merupakan salah satu metode untuk mengambil keputusan yang menggunakan algoritma pembelajaran terawasi dimana hasil dari data masukan yang baru diklarifikasi berdasarkan terdekat dalam data pelatihan. Proses perhitungan dilakukan dengan jarak terpendek data masukan terhadap data yang ada pada basis pengetahuan. Setelah ditentukan jarak terpendeknya, dapat ditarik keputusan mengenai status gizi orang tersebut, apakah dia normal, kurus, gemuk atau obesitas. Sama hal nya dengan penelitian pertama, aplikasi ini belum dilengkapi laporan status gizi balita pada tiap bulannya.

\subsection{Pengertian Sistem Pendukung Keputusan}

Sistem pendukung keputusan / Decision Support Sistem (DSS) pertama kali pada awal tahun 1970an oleh Michel S. Scott Mrton dengan nama Manegement Decision System. Konsep sistem pendukung keputusan ditandai dengan sistem berbasis komputer yang membantu pengambilan keputusan dengan memanfaatkan data modul untuk menyelesaikan masalah-masalah yang tidak teratur. Selanjutnya sejumlah perusahaan, lembaga penelitian dan perguruan tinggi mulai melakkukan penelitian dan membangun sistem pendukung keputusan[5].

\subsection{Pengertian Fuzzy Tsukamoto}

Logika fuzzy adalah metodologi sistem kontrol pemecahan masalah, yang cocok untuk diimplementasikan pada sistem, mulai dari sistem yang sederhana, sistem kecil, embedded system, jaringan PC, multichannel atau workstation berbasis akuisisi data, dan sistem kontrol. Metodologi ini dapat diterapkan pada perangkat keras, perangkat lunak, atau kombinasi keduanya. Dalam logika 
klasik dinyatakan bahwa segala sesuatu bersifat biner, yang artinya adalah hanya mempunyai dua kemungkinan, "Ya atau Tidak", "Benar atau Salah", "Baik atau Buruk", dan lain-lain[6].

\section{Metode Penelitian}

\subsection{Subjek Penelitian}

Subyek penelitian yang akan dibahas pada penelitian ini adalah di Puskesmas yang membahas mengenai penerapan Sistem Pendukung Keputusan untuk mengetahui pengelompokkan status gizi balita menggunakan Algoritma Fuzzy Tsukamoto. Selain itu juga untuk mengetahui jadwal imunisasi pada balita dan pembuatan laporan data Puskeasmas. Desain sistem yang akan diimplementasikan ke dalam bahasa pemrograman ini diharapakan dapat membantu menemukan kelompok - kelompok berdasarkan data pada balita.

\subsection{Metode Pengumpulan Data}

- Wawancara (Interview)

- Observasi

3.3 Analisis Kebutuhan

- Masukkan

- Proses

- Keluaran

\subsection{Tahap Pengembangan Sistem}

- Subsistem Data

- Subsistem Model

- Subsistem Dialog

\section{Hasil dan Pembahasan}

\subsection{Analisis Kebutuhan Sistem}

Berdasarkan analisis proses bisnis dan keadaan nyata di puskesmas pelayanan untuk memgetahui status gizi balita, didapat System Requirement Specification( SRS) atau spesifikasi kebutuhan sistem untuk sistem informasi gizi balita dan vaksinasi adalah pada tabel 1 .

Tabel 1. Daftar SRS Fungsional

\begin{tabular}{|l|l|}
\hline Kode SRS & \multicolumn{1}{c|}{$\begin{array}{c}\text { Deskrips } \\
\text { i }\end{array}$} \\
\hline SRS-F-01 & User melakukan login untuk masuk ke dalam sistem \\
\hline SRS-F-02 & Sistem mampu menyimpan data registerasi bayi \\
\hline SRS-F-03 & $\begin{array}{l}\text { Sistem mampu menghitung umur bayi berdasarkan tanggal lahir dan } \\
\text { tanggal vaksinasi }\end{array}$ \\
\hline SRS-F-04 & $\begin{array}{l}\text { Sistem mampu menentukan vaksin yang diwajibkan saat bayi akan di } \\
\text { vaksinasi }\end{array}$ \\
\hline SRS-F-05 & Sistem mampu menunjukan vaksin yang sudah dan belum diberikan \\
\hline SRS-F-06 & Sistem mampumenyimpan data vaksinasi bayi \\
\hline SRS-F-07 & Sistem mampu mengetahui status giziberdasarkanmetode fuzzy tsukamoto. \\
\hline SRS-F-08 & Sistem mampu menambah atau mengurangi data balita sesuai kebutuhan. \\
\hline SRS-F-09 & Sistem bisa edit pengguna. \\
\hline
\end{tabular}

\subsection{Perancanagan Sistem}

Setelah mendapatkan gambaran yang jelas tentang system yang akan dibuat, selanjutnya dilakukan perancangan sistem. Tahap perancangan dilakukan untuk memberikan gambaran umum yang jelas kepada pengguna dan rancang bangun yang lengkap tentang system yang akan dikembangkan kepada pihak-pihak yang terlibat dalam pengumbangan system ini. Adapun perancangan system dibagi menjadi :

1. Perancangan Algoritma

Sistem fuzzy secara umum terdapat 3 langkah dalam melakukan penalaran, yaitu :

- Fuzzifikasi : proses untuk mengubah variabel non fuzzy (variabel numerik) menjadi variabel fuzzy (variabel linguistik) 
- Inferancing : pada umumnya aturan - aturan fuzzy dinyatakan dalam bentuk "IF THEN" yang merupakan inti dari relasi fuzzy.

- Defuzifikasi : proses pengubahan data - data fuzzy tersebut menjadi data - data numerik.

2. Perancangan Proses

Pada Gambar 1. adalah use case diagram untuk Sistem Penentuan status gizi balita dengan metode tsukamoto :

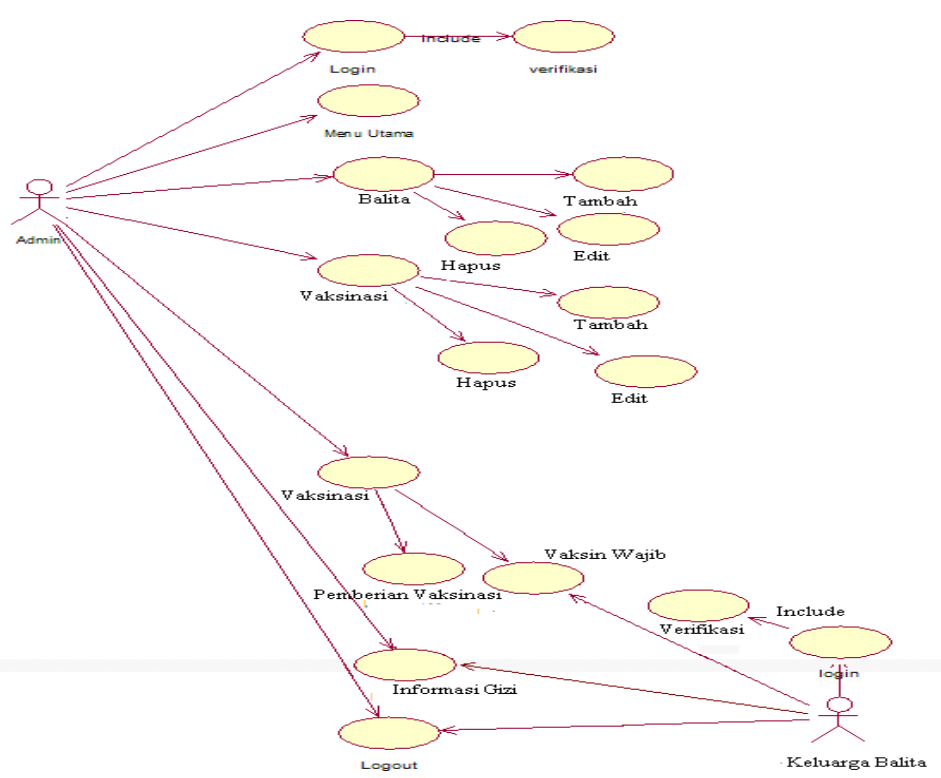

Gambar 1. Use Case Diagram Gambar

3. Perancangan Database

a. Perancangan Konseptual Awal

Perancangan konseptual awal sistem penentuan gizi dan imunisasi balita yaitu sebagai tertera pada Tabel 2 :

Tabel 2. Perancangan Entitas Sistem

\begin{tabular}{|l|l|}
\hline TipeEntitas & \multicolumn{1}{c|}{ Atribut } \\
\hline Balita & no_registerasi, nama_balita, tgl_lahir, ortu, alamat, desa, kecamatan. \\
\hline Vaksin & kd_vaksin, nama_vaksin, waktu \\
\hline Imunisasi & ID, tanggal, no_registrasi, kd_vaksin, petugas \\
\hline
\end{tabular}

b. Sequence Diagram

Pada Gambar 2. dapat dilihat alur sequence diagram untuk admin. 


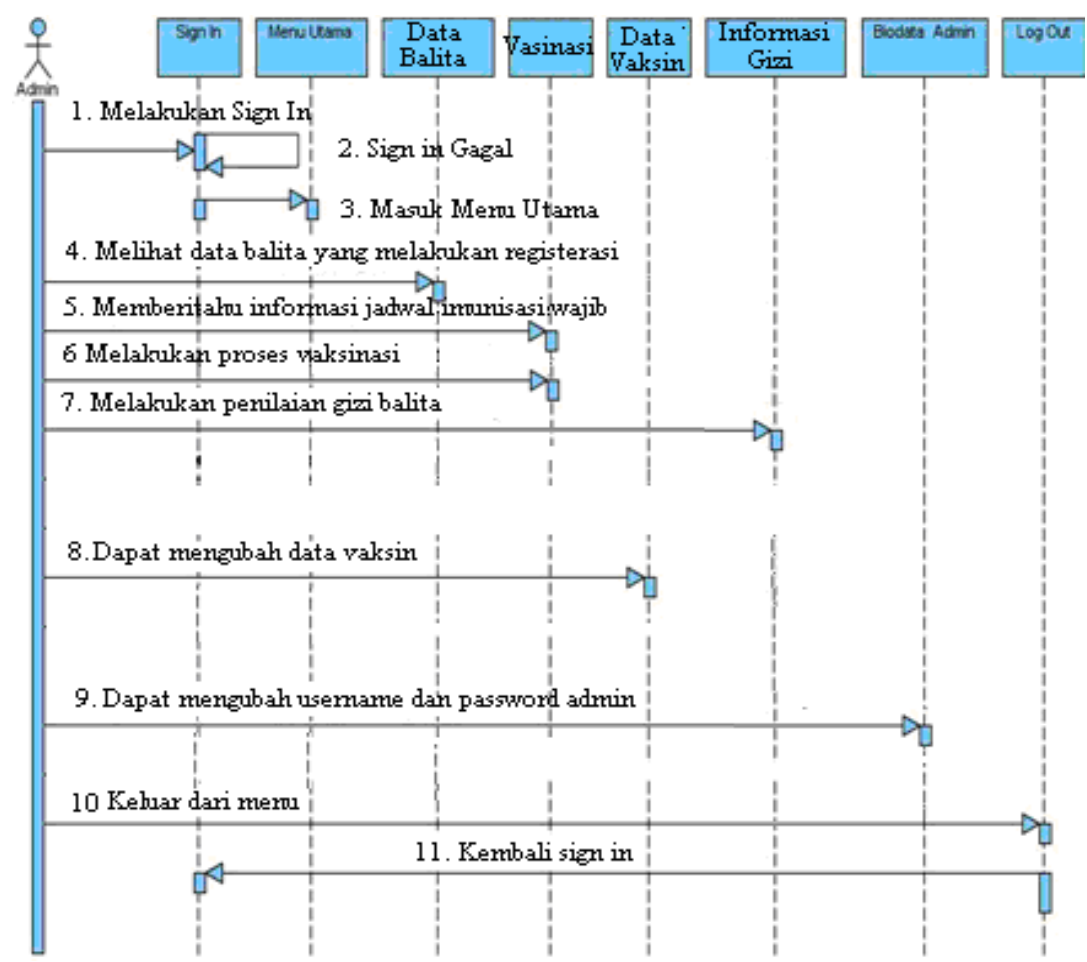

Gambar 2. Sequence Diagram Admin

Sequence diagram admin di atas dapat menjelaskan terdapat Sembilan life line, yaitu sign in, menu utama, data balita, vaksinasi, data vaksin, informasi gizi, biodata admin dan log uot. Admin melakukan Login, apabila login gagal maka kembali pada halaman login, apabila login terverifikasi maka masuk ke menu utama, melihat data balita yang melakukan registrasi, menentukan imunisasi berdasarkan data balita, memberikan informasi jadwal imunisasi, memberikan informasi gizi balita, dapat menambah, mengubah dan menghapus data balita, dapat menambah, mengubah dan menghapus data vaksin, dapat merubah username dan password admin, keluar dari menu, kembali ke tampilan login.

Dan pada Gambar 3. ini dapat dilihat alur sequence diagram untuk Keluarga Balita.Sequence diagram keluarga balita sebagaimana gambar diatas menggambarkan bahwa, pertama kali keluarga balita harus melakukan sig in, bilamana gagal maka proses sign in diulangi. Setelah keluarga balita sukses melakukan sign in maka menu utama ditampilkan. Keluarga balita hanya dapat mengakses menu informasi gizi dan jadwal imunisasi wajib, setelah selesai bidan pelamar melakukan log out, dan aplikasi kembali ke tampilan sign in.

c. Entity Relationship Diagram (ERD)

Entity Relationship Diagram (ERD) adalah diagram yang memperlihatkan entitas yang terlibat dalam suatu sistem serta hubungan-hubungan (relation) antar entitas. Model data ERD dientuk dari empat komponen dasar yaitu : Entitas, Relasi, Kardinalitas, Atribut dan Kunci. Adapun ERD dari sistem penentuan gizi dan imunisasi adalah pada gambar 4. : 


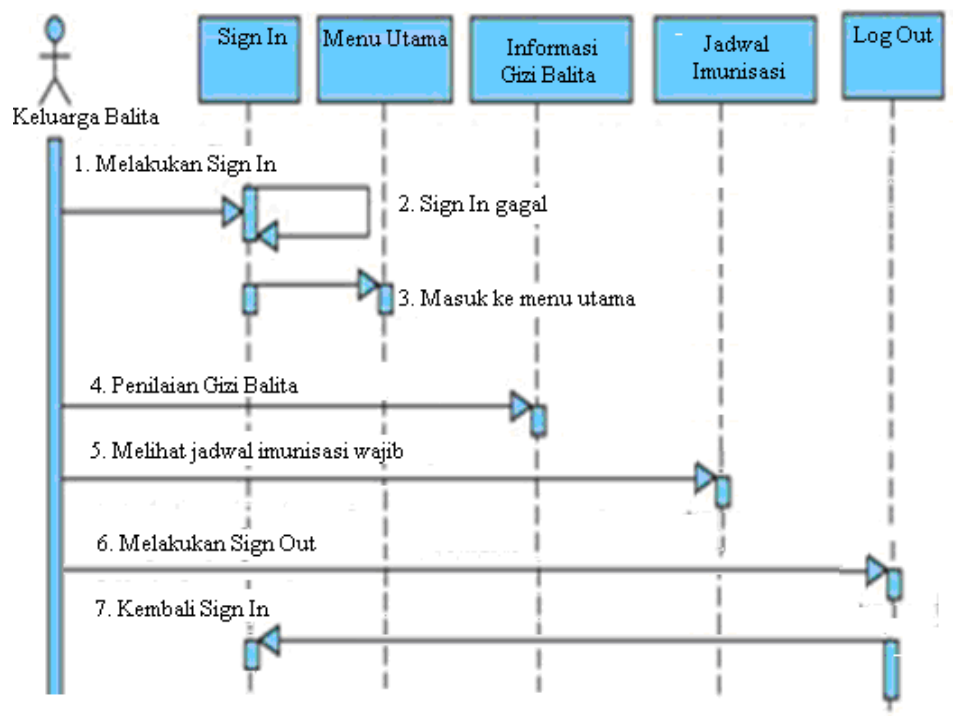

Gambar 3. Sequence Diagram Orang Tua Balita

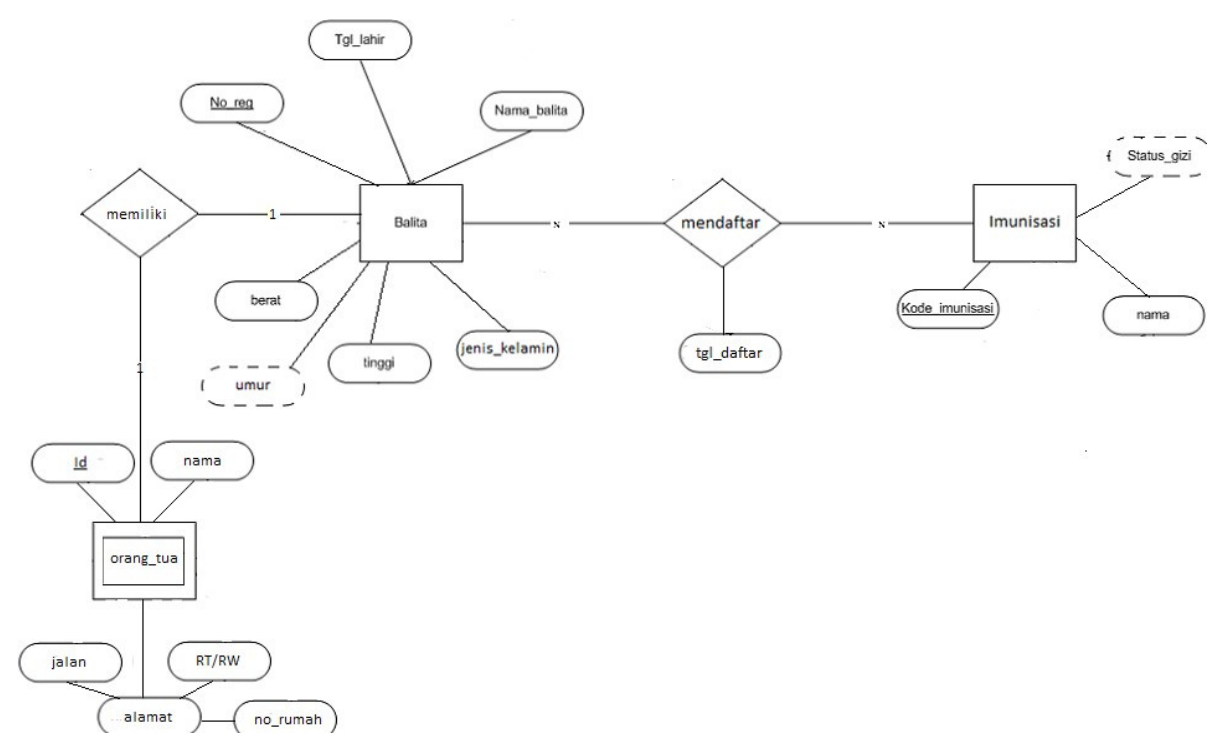

Gambar 4. Entity Relationship Diagram 


\section{d. Mapping Table}

Untuk penggambaran mapping table dapat dilihat pada gambar 5:

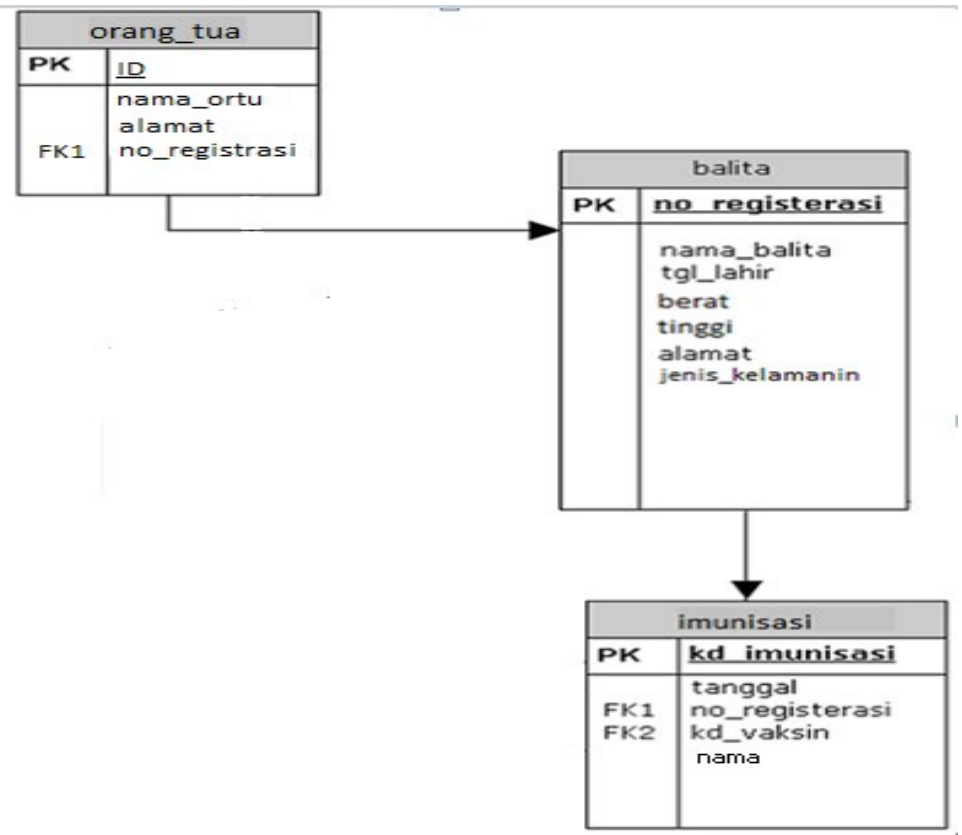

Gambar 5. Mapping Table

\subsection{Implementasi}

Pada tahap ini membahas implementasi dari analisis dan perancangan sistem yang telah dibuat. Pembahasan mencangkup implementasi basis data, daftar file yang digunakan, user interface dan modul program yang mendukung dalam membangun Sistem Pendukung Keputusan Status Gizi Balita dengan Metode Fuzzy Tsukamoto. Berdasarkan desain antarmuka diatas, akan diperoleh hasil implementasi sebagai berikut :

a. Form Log In

Gambar 6. merupakan rancangan halaman login dari semua pemakai. Sebelum masuk ke halaman utama, pemakai harus terlebih dahulu melakukan login.

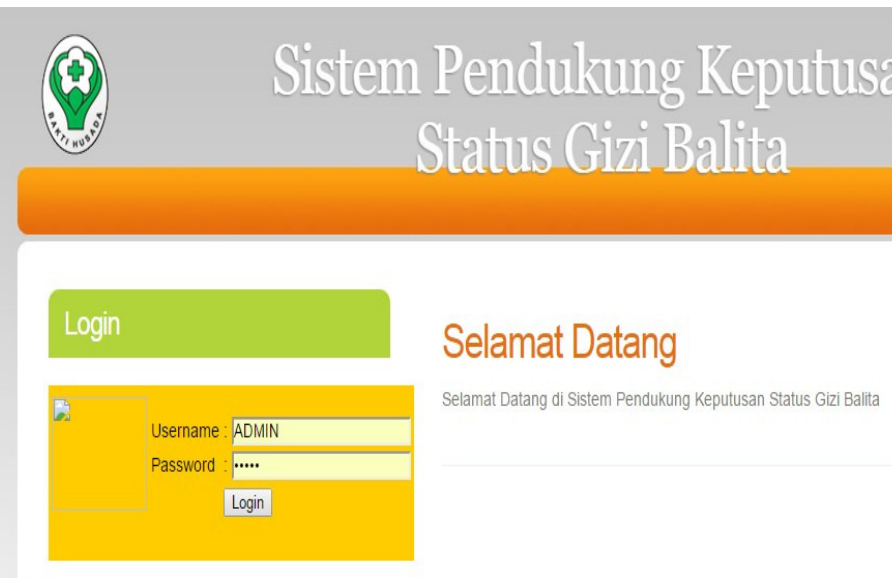

Coprriorr (c) 2012-2018 8Y

Gambar 6. Form Log 
b. Form Menu Utama

Pada Gambar 7. merupakan rancangan menu utama dalam aplikasi ini direncanakan :

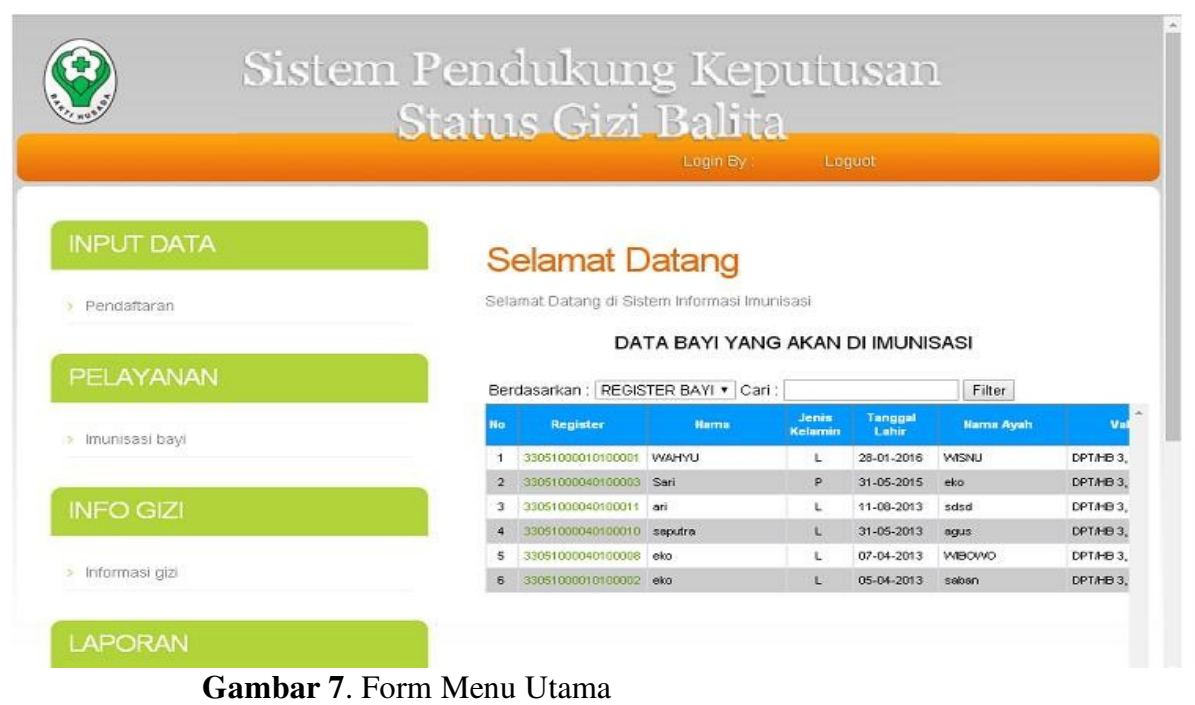

\section{c. Form Informasi Gizi Balita}

Pada gambar 8. berikut merupakan rancangan menu informasi gizi bayi dirancang mirip dengan menu proses imunisasi bayi dalam proses pemilihan data bayi yang akan dilihat status gizinya.

Selanjutnya setelah data balita dipilih dan form pengisian data tinggi dan berat badan bayi dimasukkan, akan dilanjutkan dengan hasil perhitungan nilai gizi berdasarkan metode fuzzy Tsukamoto :

Memantau Status Gizi Balita, menggunakan parameter Umur, Tinggi dan Berat - Metode Fuzzy Tsukamoto

\begin{tabular}{|l||l||}
\hline Nama & WAHYU \\
\hline \hline Umur & \multicolumn{1}{|l|}{$\mathbf{~}$} \\
\hline \hline Jenis Kelamin & Perempuan $\odot$ Laki-Laki \\
\hline Berat & $12 \quad$ Kg. (gunakan titik sebagai pemisah angka desimal) \\
\hline \hline Tinggi & $70 \quad$ Cm. (gunakan titik sebagai pemisah angka desimal) \\
\hline \hline & Back $\gg>$ \\
\hline
\end{tabular}

$\mathrm{H}$ a sil:

Nama: WAHYU

Umur: 4 bulan

Jenis Kelamin: Laki-Laki

Berat: $12 \mathrm{Kg}$

Status: GIZI BAIK

\section{Gambar 8. Form Informasi Gizi Balita}

\subsection{Pengujian Program}

Dari penilaian yang diberikan kepada Puskesmas tersebut menyatakan bahwa jawaban dari semua pertanyaan yaitu "sesuai" maka jumlah skor jawaban yang didapat adalah 6 , berdasar hasil uji kelayakan diperoleh presentasi penilaian sebagai berikut : 
- $\quad$ Bahwa pernyataan sesuai sebanyak:

6 skor jawaban $\div 6$ jumlah pertanyaan $\times 100 \%=100 \%$

- Dan pernyataan belum sesuai sebanyak :

0 skor jawaban $\div 6$ jumlah pertanyaan $\times 100 \%=0 \%$

Dari hasil penilaian terhadap sistem tersebut, maka dapat disimpulkan bahwa sistem layak untuk dipergunakan. Karena menghasilkan 100\% jawaban sesuai dan $0 \%$ jawaban belum sesuai.

\section{Kesimpulan dan Saran}

\subsection{Kesimpulan}

Dari proses analisis, perancangan dan implementasi yang dilakukan pada bab-bab sebelumnya, maka dapat diambil kesimpulan sebagai berikut:

1. Telah dihasilkan suatu Sistem Pendukung Keputusan Status Gizi Balita Metode Fuzzy Tsukamoto.

2. Sistem yang dibangun dapat dujalankan untuk pengguna yang berbeda dengan hak akses yang berbeda pula, pengguna tersebut adalah admin atau petugas yang dapat memproses semua menu.

\subsection{Saran}

Untuk pengembangan sistem selanjutnya, dapat diberikan saran-saran sebagai berikut:

1. Dari segi tampilan halaman, diharapkan untuk bisa disempurnakan tampilannya agar lebih menarik dan mengundang minat orang banyak.

2. Ditambahkan menu yang sesuai dengan kebutuhan sehingga sistem penilaian maupun pengisian data lebih efisien lagi

\section{Referensi}

[1] Supriasa, I, D, N ; Bakri, Bachhyar ; Fajar, Ibnu, 2002, Penilaian Status Gizi, Buku Kedokteran EGG, Jakarta

[2] Depkes RI. 2010. Panduan Penggunaan Kartu Menuju Sehat (KMS) Balita Bagi Petugas Kesehatan.Jakarta

[3] Latifah Alfanis , 2011, Sistem Pendukung Keputusan Penentuan Status Gizi Balita, Universitas Ahmad Dahlan

[4] Rismawan, Tedy ; Irawan, A, W ; Prabowo, Wahyu ; Kusumadewi, Sri, 2008, Sistem Pendukung Keputusan Berbasis Pocket PC Menggunakan Metode K-Nearest Neighbor, Universitas Islam Indonesia

[5]Kusrini, 2007, Konsep dan Aplikasi Sistem Pendukung Keputusan. Yogyakarta : CV. Andi Offset.

[6]Kusumadewi, Sri. dkk., 2006, Fuzzy Multi-Attribute Decision Making (FuzzyMADM), Yogyakarta : Graha Ilmu. 